\title{
SOCIAL CONFLICT DUE TO THE CONTROVERSY OF MOSQUE'S QIBLA DIRECTION IN SEJIRAM VILLAGE, SAMBAS REGENCY
}

\author{
Reza Akbar \\ Faculty of Sharia, Islamic Institute of Sultan Muhammad Syafiuddin \\ Indonesia, Jalan Raya Seiangkung No.126 Kawasan Pendidikan Tinggi Sambas \\ E-mail: reza_akbar34@yahoo.com \\ Asman \\ Faculty of Sharia, Islamic Institute of Sultan Muhammad Syafiuddin \\ Indonesia, Jalan Raya Sejangkung No.126 Kawasan Pendidikan Tinggi Sambas \\ E-mail: raja.asman86@gmail.com
}

\begin{abstract}
Determination of the direction of Qibla precisely becomes very important, especially when preparing for the construction of a mosque. A mosque that the course of Qibla can determine deviates from its intended direction; this is because of many factors, such as measurement and calculation errors, tool use errors, or errors due to the construction of the Mosque. Deviation in the direction of Qibla of a mosque can cause social conflict, such as happened in Sejiram Village, Sambas Regency, in 2010-2011. This study aims to describe the social conflict that occurred in Sejiram Village due to the controversy of the direction of the Mosque's Qibla and its impacts. This research is qualitative research with a pattern offield research through in-depth interviews to obtain primary data. Based on this research, it found that young people wanted a change in the direction of the Mosque's Qibla after it proved to the deviant. On the other hand, older people rejected it. The social conflict has an impact on the loosening of relations between parties who got involved in the conflict. However, this conflict turned out to have a positive effect, namely increasing public knowledge about the importance of accuracy in Qibla direction, encouragement to increase understanding in worship, and slowly reducing traditions that not suggested in Islam.
\end{abstract}

Keywords: Social Conflict; Qibla Direction; Sejiram; Sambas

How to Cite: Akbar, R., \& Asman, A. (2020). Social Conflict Due To The Controversy Of Mosque's Qibla Direction In Sejiram Village, Sambas Regency. Jurnal Ilmiah Al-Syir'ah, 18(1), $1-12$.

Permalink/DOI: http://dx.doi.org/10.30984/jis.v18i1.926

Copyright (C) 2020, Jurnal Ilmiah Al-Syir'ah 


\section{Jurnal Ilmiah Al-Syir'ah Vol. 18, No. 1 (2020): 1-12 \\ Website: http://journal.iain-manado.ac.id/index.php/JIS \\ ISSN 2528-0368 (online) ISSN 1693-4202 (print)}

\section{INTRODUCTION}

Facing to Qibla is an essential issue in performing prayer. In a hadith, the Prophet ordered his adherents to perfect their ablution and face to the Qibla when they will deliver the prayer (Vandestra, M., \& Muslim, 2017). Someone who is not facing the Qibla during the prayer is punished illegally, except in two conditions, namely when the khauf prayer (in a state of danger or fear) and the additional prayer carried out on the vehicle (Sahroji, 2017). Thus, determining the direction of Qibla appropriate becomes very important, especially when preparing for the construction of a mosque. Besides, determining the direction of Qibla is also needed in other places such as offices, shopping centers, and residences.

The importance correctly of facing Qibla shows the efforts of Muslims such as Abu Al-Wafa, Al-Biruni, and Ibn Al-Haytam and other experts to develop knowledge in the fields of astronomy, geodesy, and information technology. In the beginning decade, researchers developed manual methods of qibla direction based on calculation, the sun shadow, compass, and others (Sanjaya et al., 2018). As a result, to date, various methods and tools have been invented in determining the direction of Qibla, such as istiwaain developed by Slamet Hambali, Izun-Dial developed by M. Ihtirozun Ni'am, and others. There is also the determination of Qibla using celestial objects such as the sun and stars. To determine the Qiblah there are various kinds of smartphone and software applications such as Qibla \& Prayer Time applications, Qibla Direction Compass, Google Earth, and others that can use to determine Qibla direction, and their uses are very practical.

Now, using information technology advancements, someone can determine the direction of Qibla quickly, concisely, and accurately. It means one can find out whether a Mosque's Qibla direction is accurate by comparing it to various existing smartphone applications. The astronomers can not only know the deviation of the Qibla direction but by anyone who can use the Qibla direction application. Qiblah direction shows that the increasing importance of a Muslim in information technology literacy so that he can utilize various technological products for religious worship, especially in determining the direction of Qibla.

Mosques are essential needs for Muslim communities in fulfilling spiritual satisfaction because it becomes a significant obligation, especially for performing congregational prayers such as Friday prayers, 'id, and five daily prayers. Apart from its use for prayer place, mosques also become a means of reviving religious studies to increase the insight of Muslim communities and strengthen brotherhood (ukhuwah islamiyah). In the present, the mosques tend to grow and adjust the needs of people; there it is not surprising if the Mosque designed adequately, both terms the architecture and the terms the completeness of facilities.

A mosque that its direction of Qibla determined possibility to deviate from its intended path, this is caused by various factors, such as measurement/calculation errors, tool use errors, or errors due to the construction of the mosque. Deviation of Mosque's Qibla direction, for example, occurs in Jami' Mosque in Sambas Palace, 


\section{Jurnal Ilmiah Al-Syir'ah Vol. 18, No. 1 (2020): 1-12 \\ Website: http://journal.iain-manado.ac.id/index.php/JIS \\ ISSN 2528-0368 (online) ISSN 1693-4202 (print)}

West Kalimantan, in which the difference is very significant, almost 30 degrees from the direction of the initial Qibla direction. In the case of deviation of Qibla direction, problems arise when correction to the Qibla direction does not reach a convention, as happened at the Great Mosque of Demak in Central Java. Not only that, the controversy over the Mosque's Qibla direction, which could potentially lead to conflict, also occurred in other mosques, such as the Mosque in Sejiram Village, Tebas District, Sambas District, West Kalimantan. This conflict involved older people, young people, and several external mediators. It also causes clash physically (Interview to Sar' in, 23 Mei 2019).

Previous research on the deviation of Qibla direction has been carried out by Ahmad Munif, that research is motivated by the agreement of administrators, clerics, and local communities of Muslims to restore the Mosque's Qibla direction to the initial state. The results of the study were that there were two groups at loggerheads namely first, the group based on the bayânî and burhânî thinking methods that wanted a change in the Qibla direction after it proved that there was a deviation in Mosque's Qibla direction. Whereas the second group, based on the burhânî and 'irfânî thinking methods, wanted to maintain the first Mosque's Qibla direction because they believe in the nobility of science and superiority possessed by Sunan Kalijaga (Munif, 2013). The difference between the research with this study is the basic of controversy, the first base on the thinking methods (bayân $\hat{\imath}$ and burhânî) and the second based on the seniority background, namely between old and young people (Interview to Rudy, 2019).

The controversy over the Mosque's Qibla direction is a form of social conflict that occurs within the Muslim community. According to Lewis A. Coser in Wahid Nur Tualeka, Disputes that arise amid people's lives not only cause negative impacts, but also have functions that can help strengthen group ties, activate individual roles, and can improve the purpose of communication (Tualeka, 2017). Whereas according to Fisher in Mustamin, conflict is also an unavoidable reality of life and is often creative (Mustamin, 2016).

\section{RESEARCH METHODS}

This research belongs to socio-legal research that studies the implementation of Islamic law in society. This research is also qualitative because the data obtained is not numeric form, but information about social phenomena. The social events consist of the social-religious situation of the local community in Sejiram Village Sambas Regency, the historical site of the Mosque's establishment and the determination of its Qibla direction, the social conflict due to the controversy of the Mosque's Qibla direction, and its impact and efforts of community leaders in mediating the dispute. Thus, the pattern of this research is included in field research with a case study approach because the type of qualitative research included time and activity where the researcher explores the events, processes, and activities against some people (Sugiono, 2017) deeply. The location of this study is in Sejiram Village, Sambas Regency, West Kalimantan. Data collection used in this study is a deep interview to obtain primary data. The

Social Conflict Due To The Controversy Of Mosque's Qibla Direction In Sejiram Village, Sambas Regency 
Jurnal Ilmiah Al-Syir'ah Vol. 18, No. 1 (2020): 1-12

Website: http://journal.iain-manado.ac.id/index.php/JIS

ISSN 2528-0368 (online) ISSN 1693-4202 (print)

informants were community leaders of the Sejiram Village, village officials, mosque administrators, and mosque worshipers (in this case called the community).

The analysis technique in this study carried out with the models of Miles and Huberman. The process involves systematically compiling data obtained from interviews, field notes, and other materials to achieve an accurate description of social phenomena. Therefore, data analysis is carried out interactively and takes place continuously until the data is saturated, which is indicated by no new information obtained. The stages consist of data reduction, data display, and conclusions (Sugiono, 2017).

\section{RESULTS AND DISCUSSION}

\section{Social-Religious Condition of Sejiram Community}

Historically, the Sejiram Village was initially named Makrampai A. Furthermore, in 1988, the village changed its name to Sejiram Village. This village located in Tebas District, Sambas Regency, West Kalimantan. The location situated about $3 \mathrm{~km}$ from the capital of Tebas District with inadequate infrastructure conditions. The population is around 1907 people, most of whom are ethnic Malays, and all are Muslim. The main work of the local community (49.45\%) is business in agriculture, such as rice and plantations, especially oranges. Whereas, based on education level, most of its citizens have graduated from elementary school $(40.9 \%)$. However, those who have higher education, such as diplomas and scholars also exist, although the numbers are relatively low (1.52\%) (Anonim, 2019).

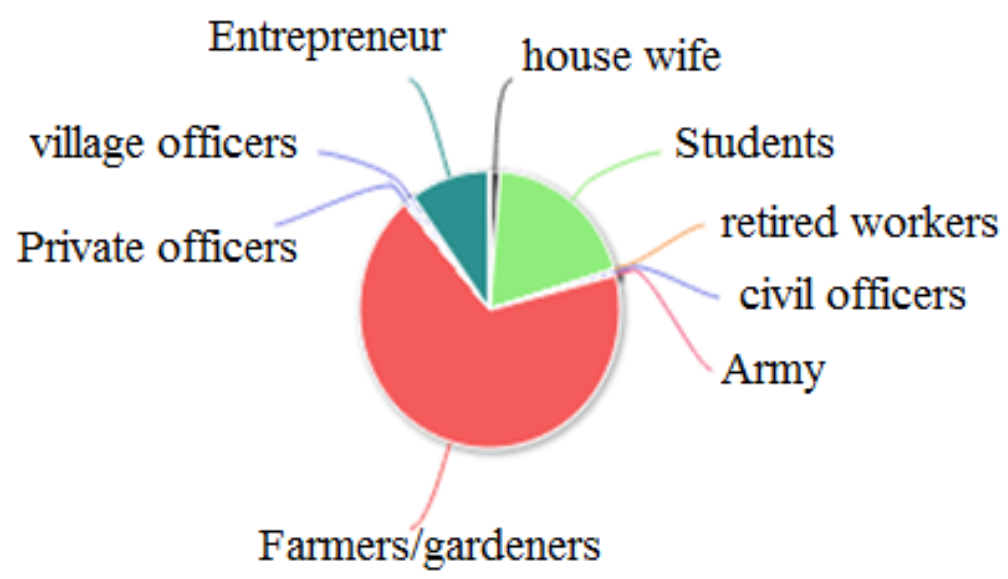

Source: http://www.desasejiram.id' 2019

Figure 1. Occupations of Sejiram Community 
Jurnal Ilmiah Al-Syir'ah Vol. 18, No. 1 (2020): 1-12

Website: http://journal.iain-manado.ac.id/index.php/JIS

ISSN 2528-0368 (online) ISSN 1693-4202 (print)

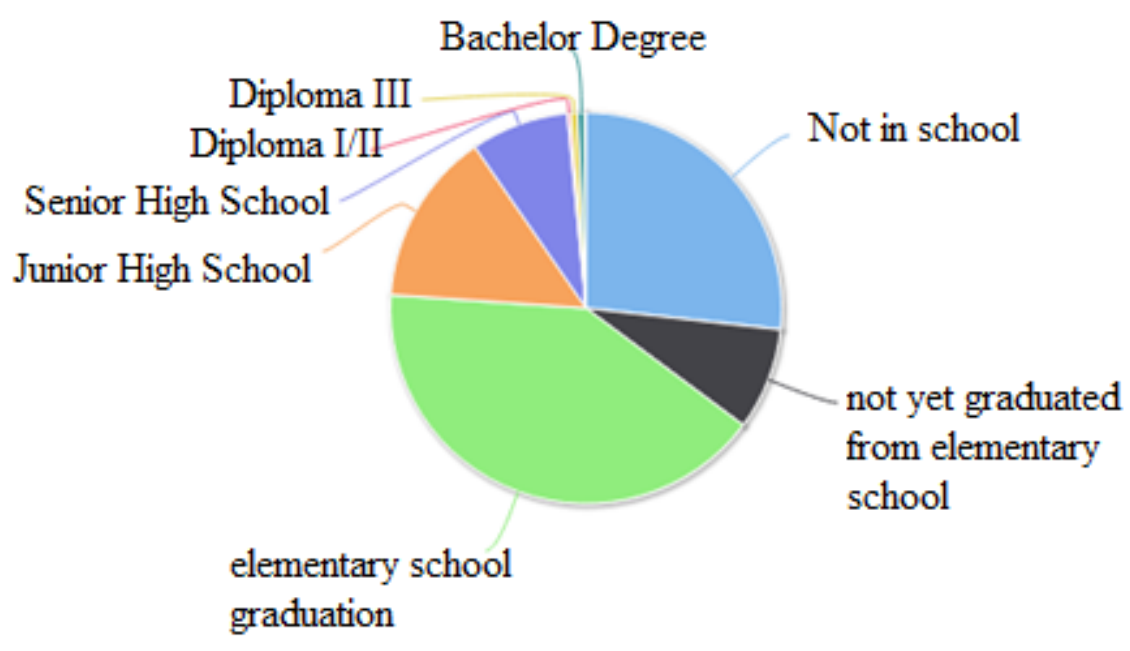

Source: http://www.desasejiram.id' 2019

Figure 2. Education Degree of Sejiram Community

In this village, there is only a single large enough mosque to accommodate around 300-400 worshipers, founded in the 1970s, and has undergone several renovations. Besides, there are three surau (small mosques) in this village, which built after 2011. Both the mosque and the surau, their existence was indeed well utilized by the local community, namely for performing five daily prayers in congregation and various activities such as Islamic activities. The performance of Friday prayers centered in this mosque.

In Sejiram Village community, some are easy to accept the changes, openminded, well adapted to technological advances, and information flows. They are generally young people. These young people are those from the local Mosque's youth, those who have sufficient education, and those who often attend Islamic gatherings. However, there are also a handful of people who find it difficult to accept changes that hold strong traditional values. This group is represented by older people who have a strong influence, both in religious and social matters. They are community leaders who are considered the most influential in the village or referred to as Pak Labbai Kampong.

\section{Deviation of the Mosque's Qibla direction in Sejiram Village}

Deviation of a Mosque's Qibla direction means inaccurate of a mosque to face Ka'bah position located in Mecca with latitude $21^{\circ} 25^{\prime} 21.17^{\prime \prime} \mathrm{N}$ and longitude 39'49'34.56" W (Muttaqien, 2018). Based on observing the Qibla direction of the mosque in this village using a pointer application tool, the Mosque's Qibla direction in Sejiram Village deviates westward (to the left). The deviation is also quite significant at around $15^{\circ} 10^{\prime}$ (fifteen degrees and ten minutes of arc). This deviation also happened in two other surau (small mosques) while the other surau measured with experts and proven to be accurate.

Social Conflict Due To The Controversy Of Mosque's Qibla Direction In Sejiram Village, Sambas Regency 
Jurnal Ilmiah Al-Syir'ah Vol. 18, No. 1 (2020): 1-12

Website: http://journal.iain-manado.ac.id/index.php/JIS

ISSN 2528-0368 (online) ISSN 1693-4202 (print)

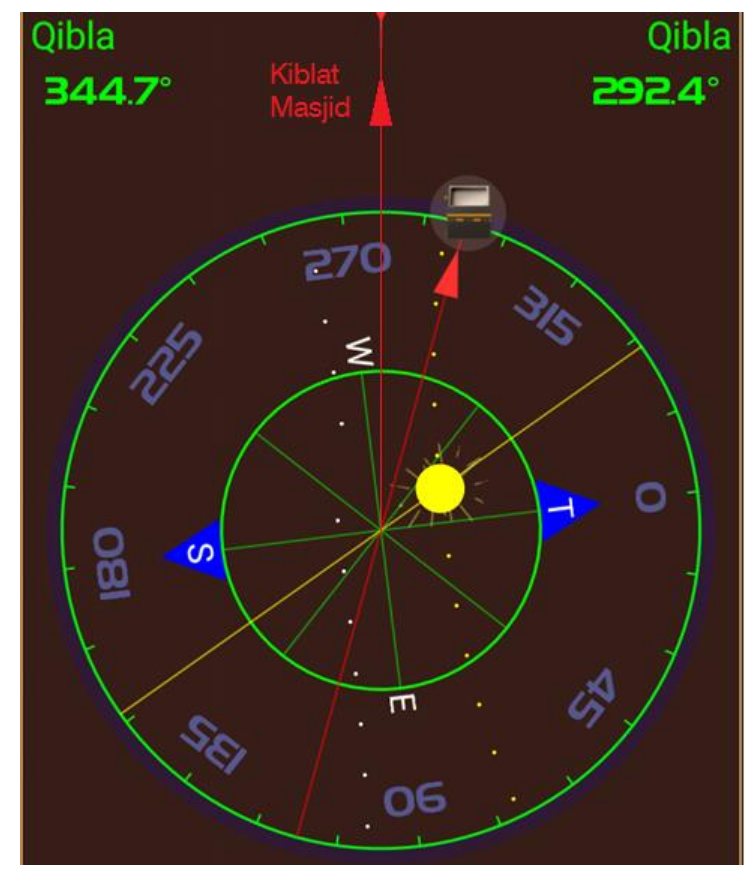

Source: Observed on May 31 ${ }^{\text {st }}, 2019$

Figure 3. Deviation of Mosque's Qibla direction in Sejiram Village

The mosque (Al-Ikhlas mosque) in Sejiram Village was built around the 1970s and renovated three times, of which the last renovation carried out in 2018. During construction, the Qibla direction was also determined by someone who was considered competent in the village, namely by Mr. Arif (deceased). However, based on Edi (36 years) from one of the community leaders and the Sejiram Village officials, the determination of the Mosque's Qibla direction was only based on the position of the sunset, without the calculation and using any tools (like a compass or others). Here, the researcher concludes that the determination of the Mosque's Qibla direction is indeed not through the right rules, but is still presumptive. Thus, the opportunity to deviate from the actual path of the Qibla is undoubtedly quite significant. The result of this misunderstanding is the direction of the cemetery in the village are because of the course of the Qibla for some people based on the position of the sun.

According to Sar'in (45 years), who is also the chief of the Mosque Management, efforts to correct the Mosque's Qibla direction have been taken in various ways, especially by Mr. Arif (deceased) as the person who was responsible for the deviation of the Mosque's Qibla direction. The efforts he has made include asking third parties such as the Sambas Regency Government, Religious Affairs Office (KUA), and the Ministry of Religion of Sambas to provide understanding to the community, especially to older people. He once testified in a forum attended by community leaders that the measurement error truly happened because the Qibla 


\section{Jurnal Ilmiah Al-Syir'ah Vol. 18, No. 1 (2020): 1-12 \\ Website: http://journal.iain-manado.ac.id/index.php/JIS \\ ISSN 2528-0368 (online) ISSN 1693-4202 (print)}

reference when building the mosque for the first time was by observing at the position of the sun or toward the west.

\section{Social Conflict Due to Controversy of the Mosque's Qibla Direction in Sejiram Village}

According to Novri Susan in St. Aisyah BM, humans are creatures of conflict (homo confliktus) because they are always involved in differences, conflicts, and competition both voluntarily and forcibly (St Aisyah, 2014). According to Thomas in Sukri, conflict is an opinion dispute between people or groups because of differences in attitudes, beliefs, values, or needs (Sukri, 2016). The conflict could see as a struggle between individuals or groups to win a goal that both want to achieve (Suparlan, 2006). Whereas according to the Constitution of Indonesia Number 7 of 2012, concerning Social Conflict Management. Social conflicts, after this referred to as conflicts feuds, and physical conflicts with violence between two groups of people and more that take place over a while and have a broad impact resulting in insecurity and disintegration social. Thus disrupting national stability and hampering national development.

Not all forms of social disharmony are called conflicts. At least there are several criteria or elements for a social phenomenon to be identified as a conflict. According to Sukardi, the items contained the conflict itself at least consist of the following criteria: 1) The existence of two or more parties involved; 2) the presence of objectives that are targeted by the conflict as well as being a source of conflict; 3) there are differences in thoughts, feelings, and actions between the parties involved achieving the goal; 4) the existence of a conflict situation between two opposing parties (Sukardi, 2016).

From some of the above meanings and explanations, social phenomena are occurring in Sejiram Village, namely controversy in the direction of the Qibla of the mosque are include in social conflict because there have differences of thoughts and actions between two groups of people (old and young) regarding the Mosque's Qibla direction for a specified period (2010-2011). This feud also involves physical clashes but is an individual. The impact has also been felt to date, namely the inconvenience of a handful of parties related to controversy of the Qibla direction so that the desire to change the Qibla direction in the right direction is still ongoing. It's just that the social conflicts that occur in Sejiram Village are local and classified as small and controllable conflicts.

According to Rudi (35 years), a village officer and used to be one of the young people, the existence of conflict among the people of Sejiram Village regarding the Mosque's Qibla direction has occurred for a long time, namely in 2010 and its climax was in 2011. This controversy began from the efforts of the young people (young and educated people in general) to recheck the Mosque's Qibla direction. The urge to recheck the Mosque's Qibla direction at least causes several factors, namely: first, the observation of the young people to several mosques in which the Mosque's Qibla direction have corrected. Qiblah direction,

Social Conflict Due To The Controversy Of Mosque's Qibla Direction In Sejiram Village, Sambas Regency 


\section{Jurnal Ilmiah Al-Syir'ah Vol. 18, No. 1 (2020): 1-12 \\ Website: http://journal.iain-manado.ac.id/index.php/JIS \\ ISSN 2528-0368 (online) ISSN 1693-4202 (print)}

there was a desire to check again whether the mosque in their village has gone in the right direction or not. Secondly, the increase of knowledge among young people, for example, the importance to face to Qibla direction appropriately as a legitimate condition of prayer. Third, the desire to recheck the Mosque's Qibla direction in the village was also motivated by an appeal received by the mosque management of the Sejiram Village issued by the Ministry of Religion in 2010. There was also the issue of shifting the Qibla direction due to a shift in the Earth's plates.

The Indonesian Ulema Council (Majelis Ulama Indonesia/MUI) issued the Fatwa of MUI No. 3 of 2010 concerning Mosque's Qibla direction in Indonesian towards the west, which revised with the Fatwa MUI No. 5 of 2010. Concerning the course of Qibla, which the determination needs calculating first, not just westward. With this issue and circulation, there is an intense desire from young people to check the Mosque's Qibla direction.

However, the plan to recheck the direction of the Mosque's course rejected (aged and uneducated people in general). The Qiblah direction is due to the belief held off a handful of older people's path of Qibla is the direction in which the sunsets. According to the older people, the course of the mosque was already correct, and no needs measuring again. The refusal to recheck the Qibla direction by the older people also initiation carried out unilaterally by the young people, without asking for the opinion of the older people. This dispute not only raises disharmony during society, but has resulted in physical conflicts, but is still individual and can resolve in a family manner, without having to go through legal procedures.

To prove that the Mosque's Qibla direction was deviating, the young people took action by presenting an astronomer (Mr. Mahdi) who was also the side of the Ministry of Religion (Kemenag) of Sambas in 2011. The steps taken by these young people are unknown to older people. The young people add to the relationship between old and young people increasingly tenuous. By local community leaders, leaders from the old and young people gathered to witness the measurements made by the Ministry of Religion, at the time of the measure, proven that the Mosque's Qibla direction did deviate quite significantly (about $20^{\circ}$ according to that time measurement).

Regarding this deviation, it was also witnessed by residents, including older people. The Ministry of Religion also recommends that the public witness the istiwaul-a' dzam (global rashdul Qibla) event, which occurs twice a year where the position of the sun is right above the $K a^{\prime} b a h$. With $K a^{\prime} b a h$, we can determine the Qibla direction, including the direction of the Qibla of the mosque, and compare it with the results of the conducted measurements. However, older people retained their beliefs.

Besides measuring the Qibla direction, the Ministry of Religion also provides alternative solutions that can be taken by the community. First, the 


\section{Jurnal Ilmiah Al-Syir'ah Vol. 18, No. 1 (2020): 1-12 \\ Website: http://journal.iain-manado.ac.id/index.php/JIS \\ ISSN 2528-0368 (online) ISSN 1693-4202 (print)}

community through the mosque administrators should adjust the direction of the Qibla by dragging the base of the prayer (prayer mat) to the right according to the measurement results (in the form of lines). That must be discussed again by community leaders so as not to cause disputes. Second, if both young and older people could not reach consensus or agreement, the community through the mosque administrators do not need to change the direction of the Qibla so that there is no conflict in the city.

In the beginning, efforts to adjust the Qibla direction were carried out by the mosque administrators by positioning the direction of the prayer mat so that it dragged from the direction of the mosque building (with the direction of the floor line) following the measured direction. However, this adjustment did not last long. The older people still refused to change the Mosque's Qibla direction. Finally, the mosque administrators chose to follow the wishes of the older people due to several factors; firstly, the older people are those who have contributed much effort, thought, and others to create a harmonious social order in the village. Secondly, the mosque administrators and community leaders want their town to return to harmony and be free from conflict. Thirdly, young people realize that the role of the older people in building mosques and teaching Islam in the village is very significant, up to the next generation. This decision to return the Qibla direction to the initial direction certainly disappoints the young. However, the disappointment of the young people is not frontal, and they can look for alternative solutions to be able to carry out prayers following the appropriate direction they believe.

Until now, the Mosque's Qibla direction in Sejiram Village returned to its initial direction. The issue of controversy has gradually dampened and is considered an old wound that once people of color's lives. Community leaders also do not want any parties to try to bring back the issue of deviation of the Qibla direction. They are convinced that the subject of the Mosque's Qibla direction will complete someday if the older people indeed initiate the Qibla direction adjustment, or this issue will quickly resolve when today's young generation replaces the old age.

\section{The Impacts of the Conflict}

According to Lewis A. Coser (1956) in Wahid Nur Tualeka, conflicts that occur during people's lives not only cause negative impacts but also they can bring positive effects (Tualeka, 2017). While according to Fisher (2001) in Mustamin, conflict is also an unavoidable challenge and often occurs creatively. Conflicts arise in compiling community goals and often result in better discussions for most or all parties involved (Mustamin, 2016). Thus, the social conflict that occurs during society does not see from a negative perspective. However, the community can also develop forward through conflict, through which conflict can adequately address.

The social conflict that has occurred in Sejiram Village due to controversy of the direction of the Qibla also has several impacts on social life. Among the effects is that at this time, the young people that question the existence of deviations in the Mosque's Qibla direction chooses to pray in other mosques (surau), which

Social Conflict Due To The Controversy Of Mosque's Qibla Direction In Sejiram Village, Sambas Regency 


\section{Jurnal Ilmiah Al-Syir'ah Vol. 18, No. 1 (2020): 1-12 \\ Website: http://journal.iain-manado.ac.id/index.php/JIS \\ ISSN 2528-0368 (online) ISSN 1693-4202 (print)}

they believe are correct. Furthermore, the Social community divided into two camps, namely the people who use the direction of the Qibla of the first mosque and the people who get this deviation from the direction of the mosque. This phenomenon, of course, can lose social relations between them because there is no understanding. Another impact is that some parties have argued about personal ties that are not harmonious, even though they are not open. In its most obvious form is the lack of greetings between them.

Aside from having a negative impact, this conflict also brings a better chance for the local community. First, the knowledge of the community about the importance of accuracy of Qibla direction is getting better and more sensitive. The evidenced when the construction of surau in this village is following the calculations and measurements following this direction is accurate. In contrast, another surau whose direction of Qibla seems to deviate immediately is corrected by striking the position of the base of prayer (prayer mat). Second, people's insight into the method of determining Qibla Direction also increases. The public knows the istiwa'ul-a'dzam event (global rashdul Qibla) which at this moment, the Qibla direction can determine because the position of the sun is right above the Ka'bah. Third, there is a critical public attitude towards a discussion of worship that does not argue. Related, the controversial conversation, direction, also encourages the public, especially the young people, to deepen their understanding in carrying out worship and not suggested in Islam to reduce traditions ultimately. In a context like this, conflict is an essential opportunity for the development of individuals and groups that make something valuable because it is acquired (Sukri, 2016).

\section{CONCLUSION}

The Mosque's Qibla direction in Sejiram Village did experience significant deviations. This deviation caused controversy, namely between the young people who wanted change and the older people who still maintained the initial direction of the mosque. This controversy causes social conflict in the form of disagreements and physical clashes but can resolve in a family manner. This social conflict that has been "forgotten" is still felt today, namely the loosening of relations between parties who got in conflict. However, this conflict turned out to have another impact, namely the increase in people's knowledge about the importance of the accuracy in Qiblah direction. The public is also aware of the istiwa'ul-a' dzam (global rashdul kiblat) event which can be used as a moment to check the Qibla direction again. The issue of the direction of the Qibla controversy also encourages the public, especially the young to deepen their understanding of worship and slowly reduce traditions that are not suggested in Islam.

\section{ACKNOWLEDGMENT}

On the contribution of this study, appreciation is worthy to people who were involved in this research, namely Sejiram village officers who were welcome for the interview and the mosque administrator who allowed to measure the qibla direction of the mosque and also for the discussion. 
Jurnal Ilmiah Al-Syir'ah Vol. 18, No. 1 (2020): 1-12

Website: http://journal.iain-manado.ac.id/index.php/JIS

ISSN 2528-0368 (online) ISSN 1693-4202 (print)

\section{REFERENCES}

Anonim. (2019). Desa Sejiram Kecamatan Kebas Kabupaten Sambas. Retrieved from desasejiran.id website: http://www.desasejiram.id/first/statistik/1

Munif, A. (2013). AnalisisKontroversi dalam Penetapan Arah Kiblat Masjid Agung demak. IAIN Walisongo Semarang.

Mustamin. (2016). Studi Konflik Sosial di Desa Bugis dan Parangina Kecamatan Sape Kabupaten Bima Tahun 2014. Jurnal Ilmiah Mandala Education, 2(2), 185-205.

Muttaqien, F. (2018). Studi Penentuan Arah Kiblat Dan Koreksi Arah Kiblat Menggunakan Kompas Digital Dan Gps Berbasis Microcontroller Arduino. In E. Suhendi \& D. Saepuzaman (Eds.), Prosiding Seminar Nasional Fisika (SiNaFi) (pp. 271-275). Bandung: Departemen Pendidikan Fisika, FPMIPA UPI.

Sahroji, M. I. (2017). Aturan Menghadap Kiblat Saat Shalat. Retrieved from NUOnline website: Sumber: https://islam.nu.or.id/post/read/82886/aturanmenghadap-kiblat-dalam-shalat

Sanjaya, W. S. M., Anggraeni, D., Nurrahman, F. I., Kresnadjaja, W. G., Dewi, I. P., Aliah, H., \& Marlina, L. (2018). Qibla Finder and Sholat Times Based on Digital Compass, GPS and Microprocessor. IOP Conference Series: Materials Science and Engineering. IOP Publishing.

St Aisyah, B. M. (2014). Konflik sosial dalam hubungan antar umat beragama. Jurnal Dakwah Tabligh, 15(2), 189-208.

Sugiono, S. (2017). Metode Penelitian Kuantitatif, Kualitatif, dan R\&D. Bandung: Alfabeta.

Sukardi. (2016). Penanganan Konflik Sosial dengan Pendekatan Keadilan Restoratif. Jurnal Hukum Dan Pembangunan, 46(1), 70-89.

Sukri. (2016). Keniscayaan Konflik dalam Masyarakat Demokrasi. Jurnal Politik Profetik, 4(2), 152-171.

Suparlan, P. (2006). NoKonflik Sosial dan Alternatif Pemecahannya. Jurnal Antropologi Indonesia, 30(2), 138-150.

Tualeka, M. W. N. (2017). Teori Konflik Sosiologi Klasik Dan Modern. AlHikmah, 3(1), 32-48.

Vandestra, M., \& Muslim, I. (2017). Kitab Hadist Shahih Muslim Ultimate. Dragon Promedia.

Social Conflict Due To The Controversy Of Mosque's Qibla Direction In Sejiram Village, Sambas Regency 
Jurnal Ilmiah Al-Syir'ah Vol. 18, No. 1 (2020): 1-12

Website: http://journal.iain-manado.ac.id/index.php/JIS

ISSN 2528-0368 (online) ISSN 1693-4202 (print)

Undang-Undang Republik Indonesia Nomor 07 Tahun 2012 Tentang Penanganan Konflik Sosial 